\title{
MANAJEMEN PENDIDIKAN ANAK USIA DINI BERBASIS PEMBELAJARAN BERPUSAT PADA ANAK: PERSPEKTIF NATURALISME ROMANTIK
}

\section{Oleh: Syamsuriadi \\ Dosen Jurusan Tarbiyah IAIN Bone}

\begin{abstract}
The management of early childhood education based on childcentered learning is a learning strategy that orients all management functions like planning, organizing, and evaluating to accelerate the children creativity during the learning process.
\end{abstract}

Keywords: The early childhood education is unique process. Hence, romantic-naturalism is a paradigm that can support the effort.

\section{PENDAHULUAN}

Pendidikan anak usia dini merupakan suatu proses pendidikan yang kompleks. Hal ini disebabkan oleh posisi anak sebagai obyek sekaligus subyek pendidikan yang sangat unik dengan beberapa karakteristik seperti tingginya ego, keaktifan yang menonjol, kaya dengan fantasi, dan berbagai karakteristik lain yang imanen dengan diri anak. Menyikapi hal tersebut, Mansur menggambarkan bahwa anak dapat diilustrasikan seperti tanaman yang tumbuh dimana pendidik harus mampu menghadirkan proses pembelajaran yang mampu mengakselerasi pertumbuhan dan perkembangan peserta didik. Suatu konsekuensi alami dari pertumbuhan tanaman adalah pertumbuhan dan perkembangan yang tergantung pada perawatan yang diberikan. ${ }^{1}$ 2011), h. 3

${ }^{1}$ Mansur, Pendidikan Anak Usia Dini dalam Islam, (Yogyakarta: Pustaka Pelajar, 
Senada dengan apa yang dikemukakan oleh Mansur di atas, Irawati Istadi mengemukakan bahwa pendidikan merupakan suatu kebutuhan yang sifatnya esensial bagi pertumbuhan dan perkembangan anak menuju kea rah yang lebih baik. Dalam konteks kehidupan modern dengan segala perkembangan teknologi yang serba cepat, kadang-kadang kecepatan perkembangan teknologi mengalahkan kecepatan perkembangan manusia. Dalam konteks tersebut, pendidikan hadir sebagai media akselerator bagi pertumbuhan dan perkembangan bagi anak. Pendidikan merupakan investasi yang menumbuhkan sumber-sumber manusia yang nilainya tidak lebih rendah dari sumber-sumber material. ${ }^{2}$

Dari ilustrasi di atas tergambar bahwa anak usia dini merupakan generasi yang memiliki potensi pertumbuhan dan perkembangan yang luar biasa sehingga harus dimaksimalkan melalui proses pendidikan. Dalam konteks ini, naturalisme romantik sebagai suatu aliran filsafat naturalisme yang berimplikasi pada psikologi pendidikan anak usia dini yang melihat peserta didik sebagai pribadi aktif dalam memahami berbagai fenomena pembelajaran yang melingkupinya.

\section{PEMBAHASAN}

\section{A. Pendidikan Anak Usia Dini}

Pendidikan anak usia dini secara konsep tidak bisa dilepaskan dari pengertian anak usia dini yang dalam konteks nasional merujuk pada anak

\footnotetext{
${ }^{2}$ Irawati Istadi, Istimewakan Setiap Anak, (Jakarta: Pustaka Inti, 2005), h. 54
} 
yang berusia antara 0 sampai 6 tahun sebagaimana telah ditegaskan dalam Undang-undang Republik Indonesia Nomor 20 tahun 2003 tentang Sistem Pendidikan Nasional pada Pasal 1 ayat 14 yang menyatakan pendidikan anak usia dini adalah pendidikan yang diperuntukkan bagi anak sejak lahir sampai usia 6 tahun. ${ }^{3}$ Dalam undang-undang Republik Indonesia Nomor 20 tahun 2003 tentang Sistem Pendidikan Nasional pada Pasal 1 ayat 14 tergambar bahwa batasan usia anak usia dini adalah sejak lahir sampai usia 6 tahun. Usia tersebut bisa dikatakan sebagai usia emas dalam perkembangan otak anak sehingga pendidikan anak usia dini sangat berpotensi memberikan hasil maksimal bagi anak.

Pendidikan anak usia dini memiliki peran yang sangat penting dalam menentukan perkembangan seorang anak pada periode umur selanjutnya. Seorang anak yang sejak usia dini sudah diperkuat dari sisi perkembangan fisik dan psikisnya akan memiliki peluang yang lebih besar untuk dapat tumbuh berkembang dengan baik dibandingkan dengan yang tidak diberikan stimulus perkembangan fisik dan psikis pada periode emas tersebut. ${ }^{4}$

Dalam kaitannya dengan prinsip, Damanhuri Rosadi menggambarkan bahwa pendidikan anak usia dini terbangun atas delapan prinsip yang dalam hal ini adalah sebagai berikut:

\footnotetext{
${ }^{3}$ Siti Aisyah et.al., Perkembangan dan Konsep Dasar Pengembangan Anak Usia Dini (Jakarta: UniversitasTerbuka, 2011), h. 1-3.

${ }^{4}$ Hibana S. Rahman, Konsep Dasar Pendidikan Anak Usia Dini, (Yogyakarta: PG TAMAN KANAK-KANAK Press, 2002), h. 6.
} 
1. Pengembangan diri, pribadi, karakter, serta kemampuan belajar anak yang pelaksanaannya tepat, terarah, cepat dan berkesinambungan.

2. Pendidikan dalam arti pembinaan dan pengembangan anak mencakup upaya pengembangan kemampuan anak dalam mengembangkan dirinya.

3. Pemanfaatan tata nilai yang dihayati anak sesuai sistem tata nilai yang berlaku pada lingkungan sosialnya dan dilaksanakan dari bawah.

4. Pendidikan anak adalah usaha sadar yang sifatnya menyeluruh, terarah, terpadu, dan dilaksanakan secara bersama dan saling menguatkan oleh semua pihak.

5. Pendidikan anak adalah suatu upaya yang didasari oleh kesepakatan sosial yang dalam hal ini adalah seluruh lapisan masyarakat.

6. Anak memiliki kedudukan sentral dalam pembangunan sehingga pendidikan anak usia dini memiliki fungsi investasi sumber daya manusia pembangunan ke depannya.

7. Orang tua dengan keteladan yang dimiliki merupakan pelaku pertama dan utama komunikasi pendidikan anak usia dini.

8. Pendidikan anak usia dini harus melingkupi inisiatif berbasis orang tua, measyarakat, serta institusi formal prasekolah. ${ }^{5}$

5 Damanhuri Rosadi, Pendidikan Anak Usia Dini dalam Kerangka Otonomi Daerah, (Jakarta: Direktorat Pendidikan Anak Usia Dini Departemen Pendidikan Nasional, 2002), h. 51-52. 
Tidak mengherankan kemudian apabila usia dini merupakan masa yang mendapatkan perhatian yang cukup besar dari berbagai pakar di bidangnya masing-masing dalam melihat usia dini ini dalam berbagai perspektifnya. Solehuddin menegaskan bahwa perhatian pakar pada usia dini paling tidak didasari oleh tiga alasan yang mendasar yang dalam hal ini adalah:

1. Usia dini merupakan usia yang sangat fundamental dalam perkembangan seorang anak. Usia dini merupakan suatu usia yang sarat dengan berbagai kejadian penting dan unik yang kemudian menjadi pijakan bagi perkembangan seseorang pada fase usia berikutnya khususnya pada usia dewasa.

2. Hakikat belajar dan perkembangan adalah suatu proses yang saling berkesinambungan dan sifatnya terus menerus. Oleh karena itu, proses awal merupakan hal yang penting karena merupakan dasar dan pondasi bagi proses belajar dan perkembangan selanjutnya.

3. Pendidikan usia dini merupakan suatu pendidikan yang memiliki dimensi aksiologis yang pada dasarnya tidak bersentuhan langsung dengan dimensi pendidikan seperti pendidikan usia dini yang sekaligus berfungsi sebagai tempat penitipan anak sebagai solusi bagi keluarga yang suami istri sibuk dalam bekerja, nilai pragmatis pendidikan usia dini yang tidak dapat disangkal menjadi suatu lahan bisnis yang menjanjikan, dan semacamnya. ${ }^{6}$

${ }^{6}$ Solehuddin, Konsep Dasar Pendidikan Pra Sekolah, (Bandung: Fakultas Ilmu Pendidikan Universitas Pendidikan Indonesia, 1997), h.46. 
Dari ilustrasi di atas, tergambar bahwa pendidikan anak usia dini mendapatkan perhatian yang besar dari berbagai pihak karena memiliki kerangka pengembangan yang jelas baik secara ontologis, epistemologis, ataupun aksiologis. Tidak mengherankan kemudian apabila pendidikan anak usia dini menjadi suatu pendidikan yang mendapatkan kerangka yuridisnormatif dari pemerintah yang salah satunya melalui termaktub dalam Peraturan Menteri Pendidikan dan Kebudayaan Republik Indonesia Nomor 137 Tahun 2014 tentang Standar Nasional Pendidikan Anak Usia Dini.

\section{B. Pembelajaran Berpusat pada Anak}

Anak dalam proses pembelajaran yang selama ini cenderung digambarkan sebagai obyek pasif harus ditransformasikan menjadi subyek aktif yang secara holistik mencurahkan segala potensi yang dimilikinya dalam proses pembelajaran. Hal ini sejalan dengan orientasi pendidikan di Indonesia sebagaimana yang tercantum dalam Peraturan Pemerintah RI Nomor 19 Tahun 2005 Pasal 19 yang berbunyi:

Proses pembelajaran pada satuan pendidikan diselenggarakan secara interaktif, inspiratif, menyenangkan, menantang, memotivasi peserta didik untuk berpartisipasi aktif, serta memberikan ruang yang cukup bagi prakarsa, kreativitas, dan kemandirian sesuai dengan bakat, minat, dan perkembangan fisik serta psikologis peserta didik. ${ }^{7}$

Dalam Peraturan Pemerintah RI Nomor 19 Tahun 2005 Pasal 19 tersebut tergambar bahwa proses pembelajaran perlu mendudukkan peserta didik sebagai subyek aktif dari proses pembelajaran yang secara tidak

${ }^{7}$ Republik Indonesia, "Peraturan Pemerintah Republik Indonesia Nomor 19 Tahun 2005 tentang Standar Nasional Pendidikan," dalam http://www.presidenri.go.id. /DokumenUU. php/ 104. pdf. (12 September 2016) 
langsung memotivasi mereka dalam melibatkan diri pada berbagai aktivitas pembelajaran yang diberikan.

Paradigma pembelajaran berpusat pada anak menuntut pelibatan anak dalam proses pembelajaran secara maksimal baik dari domain kognitif, psikomotorik, ataupun afektifnya. Dalam konteks tersebut, pemahaman yang komprehensi terhadap kepribadian anak akan memudahkan pendidik dalam mengkonstruk kegiatan pembelajaran yang berpusat pada anak. Dalam konteks tersebut, Ma'ruf Zuraiq menggambarkan beberapa kepribadian yang melekat pada anak yang dalam hal ini adalah:

1. Anak dapat bergerak lebih banyak bergerak, bermain tanpa mengenal waktu, bahkan terkadang lupa untuk makan dan minum. Dengan kepribadian ini, untuk mewujudkan pembelaajaran yang berpusat pada anak, kegiatan pembelajaran harus mengakomodir kepribadian anak tersebut dengan porsi pembelajaran yang mampu menarik minat belajar mereka dengan banyak bergeraksecara aktif.

2. Anak memiliki sifat yang individualistis sehingga keinginankeinginannya yang sifatnya individualistis tersebut harus selalu terpenuhi. Dengan kepribadian ini, untuk mewujudkan pembelaajaran yang berpusat pada anak, kegiatan pembelajaran harus mempu menjembatani keinginan-keinginan individualistis anak dengan menjembatani keinginan-keinginan individualistis tersebut menjadi keinginan kolektif. 
3. Anak cenderung memposisikan benda mati sebagai benda hidup seperti berbicara dengan boneka, gambar, dan semacamnya. Dengan kepribadian ini, untuk mewujudkan pembelajaran yang berpusat pada anak, kegiatan pembelajaran harus mampu memposisikan berbagai media pembelajaran yang berupa benda-benda mati sebagai sarana pembelajaran yang

4. Anak hanya merasa hidup untuk pada hari ini saja tanpa ada pertimbangan akan masa lalu ataupun masa mendatang. Dengan kepribadian ini, untuk mewujudkan pembelajaran yang berpusat pada anak, kegiatan pembelajaran harus mampu memberikan efek pembelajaran yang bersentuhan dengan dunia kekinian mereka.

5. Anak cenderung selalu memiliki keinginan besar yang harus diwujudkannya meskipun keinginan besar yang dimaksud merupakan bagian dari fantasinya. Dengan kepribadian ini, untuk mewujudkan pembelajaran yang berpusat pada anak, kegiatan pembelajaran harus mampu mengembangkan potensi anak dalam dunianya yang penuh dengan fantasi.

6. Anak cenderung lebih memahami apa yang yang bersifat konkret dan dialami olehnya secara langsung. Dengan kepribadian ini, untuk mewujudkan pembelajaran yang berpusat pada anak, kegiatan pembelajaran harus mampu memberikan pemahaman secara langsung pada anak dengan sifatnya yang konkret. 
7. Setiap anak memiliki karakter masing-masing dan cenderung berbeda satu sama lain. Dengan kepribadian ini, untuk mewujudkan pembelajaran yang berpusat pada anak, kegiatan pembelajaran harus mampu mengakomodir perbedaan individu (individual differences) yang imanen pada setiap manusia termasuk anak.

8. Anak adalah anak dengan dunianya yang khas yang tentunya berbeda dengan dunia orang dewasa. Dengan kepribadian ini, untuk mewujudkan pembelajaran yang berpusat pada anak, kegiatan pembelajaran harus mampu jeli melihat kekhasan dunia anak lalu diolah sebagai sarana pembelajaran. ${ }^{8}$

Apa yang digambarkan oleh Ma'ruf Zuraiq tersebut menunjukkan bahwa anak merupakan makhluk sosial yang memiliki karakter khas yang harus diakomodir dalam mewujudkan pembelajaran yang berpusat pada anak.

\section{Manajemen Pendidikan Anak Usia Dini Berbasis Pembelajaran Berpusat pada Anak: Perspektif Naturalisme Romantik}

Naturalisme romantik sebagai suatu aliran psikologi yang digagas pertama kali oleh yang mengarahkan anak dalam upaya memberdayakan segala potensi yang dimilikinya dalam memahami situasi belajarnya secara alami. Menurut Rousseau, anak memiliki potensi atau kekuatan yang masih terpendam, yaitu potensi berfikir, berperasaan, berkemauan, keterampilan, berkembang, mencari dan menemukan sendiri apa yang diperlukannya

\footnotetext{
${ }^{8}$ Ma'ruf Zuraiq, Kaifa Nurabbi Abnaaana, (Beirut: Dar Fikri, 1983), h. 14-15
} 
melalui berbagai bentuk kegiatan dan usaha belajar, anak mengembangkan segala potensi yang dimilikinya. Berbeda dengan teori lain, menurut Rousseau anak tidak usah terlalu banyak diatur dan diberi. Biarkan mereka mencari dan menemukan dirinya sendiri. Sebab menurut dia, anak dapat berkembang sendiri. ${ }^{9}$

Paradigma naturalisme romantik tersebut sejalan dengan apa yang digambarkan oleh Dindin Jamaluddin bahwa membentuk pribadi anak sebagai insan yang sempurna harus mengakselerasi anak menyelesaikan sendiri permasalahan yang dihadapinya. ${ }^{10}$ Dalam mewujudkan tersebut, anak diberikan akses yang luas dalam mengembangkan kegiatan pembelajarannya meskipun tetap diawasi oleh pendidik. Dalam konteks ini, manajemen pendidikan anak usia dini berbasis pembelajaran berpusat pada anak harus mengarah pada potensi dan karakteristik dunia anak itu sendiri.

Dunia anak identik dengan kegiatan bermain sehingga bisa dikatakan bahwa merupakan fitrah apabila anak cenderung memperlihatkan keaktifan apabila dibelajarkan dengan teknik bermain. Menyikapi hal tesebut, M. Fauzi Rachman dengan mengutip pendapat Hughes, seorang pakar perkembangan anak, menggambarkan bahwa bermain yang cenderung disenangi oleh anak paling tidak mengandung beberapa unsur yang dalam hal ini adalah:

\footnotetext{
1996), h. 14

10 Dindin Jamaluddin, Paradigma Pendidikan Anak dalam Islam, (Bandung: Pustaka Setia, 2013), h. 40.
}

${ }^{9}$ R. Ibrahim dan Nana Syaodih, Perencanaan Pengajaran (Jakarta: Rineka Cipta, 
1. Tujuan permainan adalah permainan itu sendiri dan pelaku permainan cenderung mendapatkan kepuasan karena melakukannya.

2. Permainan dipilih sendiri secara bebas serta dilakukan atas kehendak sendiri tanpa adanya pihak lain yang memaksa.

3. Permainan menyenangkan dan dinikmati.

4. Permainan memiliki unsur khayalan di dalamnya.

5. Permainan dilakukan secara aktif dan sadar. ${ }^{11}$

Agar pembelajaran yang berpusat pada anak dapat dievaluasi secara komprehensif, ada beberapa prinsip penilaian yang harus diterapkan yang dalam hal ini digambarkan oleh Mansur sebagai berikut:

1. Holistik: Prinsip berarti bahwa penilaian yang dilakukan harus meliputi seluruh aspek perkembangan anak usia dini yang dalam hal ini adalah fisik motorik, sosial, moral, emosional, intelektual, bahasa, serta kreativitas.

2. Otentik: Prinsip ini berarti bahwa penilaian yang dilakukan melalui kegiatan nyata, fungsional, dan alami sehingga hasil penilaian yang dilakukan memiliki otentitas dalam menggambarkan kemampuan anak yang sesungguhnya.

3. Berkelanjutan: Prinsip ini berarti bahwa penilaian yang dilakukan selalu berkelanjutan selama proses pembelajaran berlangsung.

${ }^{11}$ M. Fauzi Rachman, Islamic Parenting, (Jakarta: Penerbit Erlangga, 2011), h. 80- 
4. Individual: Prinsip ini berarti bahwa penilaian yang dilakukan harus terfokus pada pekembangan individual setiap anak sehingga kelebihan, kekurangan, serta kebutuhan mereka dapat dipahami.

5. Multisumber dan multikonteks: Prinsip ini berarti bahwa penilaian yang dilakukan dengan menggunakan berbagai sumber dan konteks demi memahami perkembangan motorik halus setiap anak. ${ }^{12}$

Agar manajemen pendidikan anak usia dini berbasis pembelajaran berpusat pada anak tersebut dapat terwujud dalam kerangka praktisnya, naturalisme romantik melihat bahwa berbagai prinsip penilaian di atas harus dikaitkan dengan fungsi-fungsi manajemen yang lainnya seperti perencanaan dan pengorganisasian sebagai suatu kesatuan yang utuh. Konsekuensinya, prinsip holistik, otentik, berkelanjutan, individual, serta multisumber ataupun multikonteks juga harus melekat pada fungsi-fungsi manajemen yang lainnya.

\section{KESIMPULAN}

Manajemen pendidikan anak usia dini berbasis pembelajaran berpusat pada anak merupakan suatu paradigma pembelajaran yang dalam perspektif naturalisme romantik dipandang sebagai suatu strategi pembelajaran yang mampu mengakselerasi potensi anak secara maksimal. Fungsi-fungsi manajemen harus diakselerasikan sebagai suatu kesatuan yang utuh dalam mendukung akselerasi potensi anak tersebut tersebut.

\footnotetext{
${ }^{12}$ Mansur, Pendidikan Anak Usia Dini dalam Islam, h. 77
} 


\section{REFERENSI}

Aisyah, Siti et.al., Perkembangan dan Konsep Dasar Pengembangan Anak Usia Dini, Jakarta: UniversitasTerbuka, 2011.

Ibrahim, R. dan Nana Syaodih, Perencanaan Pengajaran, Jakarta: Rineka Cipta, 1996.

Istadi, Irawati, Istimewakan Setiap Anak, Jakarta: Pustaka Inti, 2005.

Jamaluddin, Dindin, Paradigma Pendidikan Anak dalam Islam, Bandung: Pustaka Setia, 2013.

Mansur, Pendidikan Anak Usia Dini dalam Islam, Yogyakarta: Pustaka Pelajar, 2011.

Rachman, M. Fauzi, Islamic Parenting, Jakarta: Penerbit Erlangga, 2011.

Rahman, Hibana S., Konsep Dasar Pendidikan Anak Usia Dini, Yogyakarta: PG TAMAN KANAK-KANAK Press, 2002.

Republik Indonesia, "Peraturan Pemerintah Republik Indonesia Nomor 19 Tahun 2005 tentang Standar Nasional Pendidikan," dalam http://www.presidenri.go.id. /DokumenUU. php/ 104. pdf. (12 September 2016)

Rosadi, Damanhuri, Pendidikan Anak Usia Dini dalam Kerangka Otonomi Daerah, Jakarta: Direktorat Pendidikan Anak Usia Dini Departemen Pendidikan Nasional, 2002.

Solehuddin, Konsep Dasar Pendidikan Pra Sekolah, Bandung: Fakultas Ilmu Pendidikan Universitas Pendidikan Indonesia, 1997.

Zuraiq, Ma’ruf, Kaifa Nurabbi Abnaaana, Beirut: Dar Fikri, 1983. 